\title{
PENGEMBANGAN LKS BERBASIS RME DENGAN PENDEKATAN PROBLEM SOLVING UNTUK MEMFASILITASI KEMAMPUAN PEMECAHAN MASALAH MATEMATIS SISWA
}

\author{
Adityawarman Hidayat ${ }^{1}$, Indra Irawan $^{2}$ \\ ${ }^{1}$ Universitas Pahlawan Tuanku Tambusai, Jln. Tuanku Tambusai No.23 Bangkinang \\ ${ }^{2}$ Universitas Pahlawan Tuanku Tambusai, Jln. Tuanku Tambusai No.23 Bangkinang \\ adityawarmanhidayat@ymail.com
}

\begin{abstract}
This research is a research development $(R \& D)$ model that aims to develop a Realistic Mathematics Education (RME) based Worksheet (LKS) with a valid and practical problem solving approach to facilitate the mathematical problem solving ability of grade 3 students of Elementary School 012 KP .Airtiris Length. The product developed in this research is LKS Lecture Material with Counting Material of Numbers, Measurement and Relation Base on RME basis with problem solving approach for third grade students of Elementary School. The development model is carried out in accordance with the ADDIE Model, ie analysis, Design, Development, Implementation, and Evaluation. Instruments used in this research are validity test sheet, practicality test sheet, and postes problem. Based on the validity test results, the RME-based LKS with the problem solving approach included in the category is very valid with the percentage of $81 \%$. While the test results of practicality during large group trials, LKS based on RME with problem solving approach including very practical category with the percentage of $94.07 \%$. Based on the result of postes, students' math problem solving ability has been classified as good with percentage of $79,14 \%$.
\end{abstract}

Keywords: Realistic Mathematics Education based Worksheet, Problem Solving Approach, MathematicalProblemSolvingAbility

\begin{abstract}
Abstrak
Penelitian ini merupakan model penelitian pengembangan $(R \& D)$ yang bertujuan untuk mengembangkan Lembar Kerja Siswa (LKS) berbasis Realistic Mathematics Education (RME) dengan pendekatan pemecahan masalah yang valid dan praktis untuk memfasilitasi kemampuan pemecahan masalah matematissiswa kelas III Sekolah Dasar Negeri 012 KP. Panjang Airtiris. Produk yang dikembangkan dalam penelitian ini berupa bahan ajar LKS dengan materi Operasi Hitung Bilangan, Pengukuran dan Hubungan Antarsatuanberbasis RME dengan pendekatan pemecahan masalah untuk siswa kelas III Sekolah Dasar. Model pengembangan yang dilakukan sesuai dengan Model ADDIE, yaitu analisis (Analysis), desain (Design), pengembangan (Development), implementasi (Implementation), dan evaluasi (Evaluation). Instrumen yang digunakan dalam penelitian ini adalahlembar uji validitas, lembar uji praktikalitas, dan soal postes. Berdasarkan hasil uji validitas, LKS berbasis RME dengan pendekatan pemecahan masalah termasuk dalam kategori sangat valid dengan persentase $81 \%$. Sedangkan hasil uji praktikalitas saat uji coba kelompok besar, LKS berbasis RME dengan pendekatan pemecahan masalah termasuk kategori sangat praktis dengan persentase 94,07\%. Berdasarkan hasil postes, kemampuan pemecahan masalah matematika siswa sudah tergolong baik dengan persentase $79,14 \%$.
\end{abstract}

Kata Kunci: Lembar Kerja Siswa berbasis RME, Pendekatan Problem Solving, Kemampuan Pemecahan Masalah Matematis

Matematika memiliki tujuan yang sangat penting bagi peserta didik di sekolah.Peraturan Menteri Pendidikan dan Kebudayaan RI Nomor 54 tahun 2013 tentang standar kompetensi lulusan Pendidikan Dasar dan Menengah menjelaskan, bahwa tujuan pembelajaran matematikadi sekolah antara lain memiliki keterampilan dalam berfikir dan tindak yang efektif untuk memecahkan masalah yang meliputi kemampuan memahami masalah, merancang model matematika, menyelesaikan model dan menafsirkan solusi yang diperoleh. 
Permasalahan yang sering dijumpai pada peserta didikkhususnya pada matematika adalah prestasi matematika rendah. Kenyataanmasihbanyak kita jumpai siswa yang prestasi matematikanyarendah, salah satu ukuran melihat kemampuan pemecahan masalah matematis siswa adalah hasil TIMSS(Trends in Mathematics and Scienci Study) yang diikuti oleh 600.000 siswa yang dites dari 63 negara menyebutkan bahwa Indonesia berada di urutan ke-38 dengan skor 386 dari 42 negara untuk bidang matematika. Pada TIMSS matematika tersebut, peringkat pertama diraih siswa korea dengan skor 613, skor Indonesia ini turun 11 poin (Berita Terkini, 17 Desember 2012:13). Hasil tersebut menunjukkan bahwa kemampuan siswa Indonesia masih tergolong rendah dan belum terbiasa dengan soal-soal yang menuntut siswa untuk berpikir, bernalar, dan pemecahan masalah matematis.

Berdasarkan hasil wawancara dengan guru matematika SDN 012 KP. Panjang Airtiris tanggal 4 April 2016, siswa cenderung mengalami kesulitan dalam menyelesaikan soal-soal yang berbentuk soal pemecahan masalah (problem solving). Hal ini sejalan dengan pendapat Nenden (dalam Supriatna, 2015:31) bahwa soal-soal yang berbentuk pemecahan masalah umumnya belum mampu dikuasai oleh siswa. Ini dapat dilihat dalam menyelesaikan soal tidak rutin, yaitu soal yang memiliki tingkat kesulitan tinggi dan memerlukan kemampuan pemecahan masalah matematika, siswa mengalami kesulitan dalam menyelesaikannya. Hal ini terjadi karena siswa belum mampu memahami masalah dengan baik yang mengakibatkan siswa mengalami kesulitan dalam menyelesaikan soal pemecahan masalah.

Salah satu bahan ajar yang dapat dikembangkan adalah Lembar Kerja Siswa (LKS). Penggunaan LKS dalam pembelajaran matematika dapat mendorong siswa untuk mempelajari materi ajar sendiri atau bersama dengan teman kelompoknya. Oleh karena itu, sebuah LKS harus berisi pembelajaran yang sesuai dengan karakteristik siswa dan mampu membuat siswa merasakan pembelajaran yang bermakna.

Berdasarkan observasi yang dilakukan di SDN 012 KP.Panjang Airtiris pada tanggal 5 April 2017, diperoleh bahwa sekolah tersebut menggunakan bahan ajar berupa LKS Matematika. LKS tersebut masih berisi rangkuman materi dan soal-soal objektif atau uraian singkat. Berdasarkan fakta tersebut terlihat bahwa LKS yang biasa digunakan siswa dalam pembelajaran di sekolah masih berisi rangkuman materi disertai dengan soal-soal berbentuk objektif atau uraian singkat. Materi yang disajikan belum berawal dari sesuatu yang riil, begitu juga dengan soal yang diberikan juga belum berawal dari masalah nyata (Realistics). Soal diberikan langsung dalam bentuk matematika formal, sehingga penggunaan LKS belum dapat memfasilitasi kemampuan pemecahan masalah matematika siswa. Oleh karena itu, perlu mengadakan suatu pengembangan bahan ajar berupa Lembar Kerja Siswa (LKS) berbasis Realistic Mathematics Education (RME) dengan menggunakan pendekatan pemecahan masalah (Problem Solving). Pembelajaran menggunakan LKS berbasis RME dengan pendekatan Problem Solving ini diawali dengan masalah dunia nyata, sehingga siswa dapat menggunakan pengalamannya, mengkonstruksi sendiri melalui pengetahuan sebelumnya yang ada hubungannya dengan kehidupan sehari-hari dan menjadikan pembelajaran lebih bermakna sehingga 
diharapkan dapat memfasilitasi kemampuan pemecahan masalah matematis siswa di SDN $012 \mathrm{KP}$. Panjang Airtiris.

Matematika yang merupakan ilmu dengan objek abstrak dan dengan pengembangan melalui penalaran deduktif telah mampu mengembangkan model-model yang merupakan contoh dari sistem itu yang pada akhirnya telah digunakan untuk memecahkan persoalan dalam kehidupan sehari-hari. Matematika juga dapat mengubah pola pikir seseorang menjadi pola pikir yang matematis, sistematis, logis, kritis dan cermat. Tetapi sistem matematika ini tidak sejalan dengan tahap perkembangan mental anak, sehingga yang dianggap logis dan jelas oleh orang dewasa pada matematika, masih merupakan hal yang tidak masuk akal dan menyulitkan bagi anak. Faktor-faktor lain yang harus diperhatikan dalam proses pembelajaran matematika, selain bahwa tahap perkembangan berpikir siswa SD belum formal atau masih konkrit adalah adanya keanekaragaman intelegensi siswa SD serta jumlah siswa SD yang cukup banyak dibandingkan guru yang mengajar matematika. Matematika yang dipelajari oleh siswa SD dapat digunakan oleh siswa SD untuk kepentingan hidupnya sehari-hari dalam kepentingan lingkungannya, untuk membentuk pola pikir yang logis, sistimatis, kritis dan cermat dan akhirnya dapat digunakan untuk mempelajari ilmu-ilmu yang lain.

Realistic Mathematics Education (RME) memberikan kesempatan kepada siswa untuk belajar mengalami langsung dari proses pembelajaran yang diberikan. Saat merancang kegiatan mengajar, seorang guru harus menggunakan indikator kompetensi sebagai tolak ukur dan integrasinya dengan bahan ajar untuk mengubahnya menjadi konten pelajaran, sehingga nantinya ini dapat membantu siswa memahami kekuatan dan kelemahan mereka dalam pembelajaran dan dapat membimbing siswa dalam merefleksi diri dan memperbaiki pembelajaran mereka (Chiang, 2015). Seperti halnya dengan pembelajaran RME, penerapan pembelajaran RME ini memberi kesempatan kepada siswa untuk secara aktif membangun pemahaman mereka sendiri sebagai alat bantu dalam pembelajaran matematika. Guru harus bisa menciptakan kegiatan yang diharapkan dalam pembelajaran Matematika menggunakan RME sehingga apapun kegiatan yang dilakukan dan dijalani oleh siswa akan bermakna dan mereka akan berkembang menjadi pelajar formal (Arsaythamby, 2014). Dengan demikian, guru harus mampu memberikan panduan pembelajaran yang tepat dalam penerapan RME dan menggunakan tahapan-tahapan yang jelas sehingga dapat membantu hasil belajar matematika siswa.

Problem solving atau dikenal dengan pemecahan masalah merupakan hal yang tidak mudah dalam pembelajaran matematika bagi siswa ataupun dalam penerapan pendekatan problem solving bagi seorang guru. Sebagai calon guru, dalam menerapkan pendekatan pemecahan masalah mestilah menggunakan pemecahan masalah yang cukup jelas dan teratur dalam beberapa pertanyaan yang memerlukan pencarian operasi, formula ataupun pola (Bayrakdar, 2011). Disamping itu, contohcontoh masalah yang ada dalam buku mestilah mempertimbangkan masalah rutin dalam pelajaran yang diberikan, yang mana jangan sampai masalah tersebut tidak menarik perhatian para siswa, 
sehingga mereka tidak dapat mengerjakan sesuai kemampuan dan tidak mengalami masalah tersebut pada kejadian serupa dalam kehidupan nyatanya (Kar et al, 2010). Jadi, pemecahan masalah yang direncanakan atau dibuat oleh guru haruslah betul-betul di rencanakan dan jelas prosedur yang akan di lalui oleh siswa karena itu merupakan elemen penting dalam sebuah pendekatan pemecahan masalah.

Lembar Kerja Siswa (LKS) yang dikembangkan dalam penelitian ini berbasis Realistic Mathematics Education (RME) dengan pendekatan problem solving yang merupakan salah satu pendekatan yang mengarahkan siswa memahami konsep matematika dengan mengkonstruksi sendiri melalui pengetahuan sebelumnya yang ada hubungannya dengan kehidupan sehari-hari serta memberi kesempatan siswa membangun kemampuan berpikir matematis. Penulisan LKS ini disusun berdasarkan objek yang ada di lingkungan siswa, dan juga berkaitan dengan permasalahan yang mudah dijumpai dan dibayangkan oleh siswa. Dengan demikian, LKS ini dapat membantu siswa untuk mengembangkan kemampuan, menerapkan pengetahuan, melatih keterampilan, dan memproses sendiri dalam memecahkan masalah matematika. Dalam penyusunan LKS, pembelajaran dimulai dengan memberikan masalah kontekstual yang berkaitan dengan kehidupan sehari-hari. LKS disusun dengan menggunakan model-model, skema, simbol atau lain sebagainya. Di dalam LKS, siswa diarahkan untuk mengolah masalah kontekstual menggunakan bahasa atau model dan simbol yang dibuat sendiri oleh siswa. Terlebih dahulu siswa menyelesaikan masalah tersebut dengan cara mereka masing-masing. Setelah itu, dilakukan proses menuju pada perumusan matematika formal. Di samping itu, soal-soal dan latihan dalam LKS dibuat untuk memfasilitasi kemampuan pemecahan masalah matematis siswa. Siswa diarahkan bagaimana menyelesaikan masalah atau soal dengan mengikuti langkah-langkah pemecahan masalah matematika, yang dimulai dari memahami masalah, membuat perencanaan penyelesaian, melaksanakan penyelesaian dan memeriksa kembali hasil yang diperoleh.

Menurut Polya (dalam Tarigan, 2006:155), belajar pemecahan masalah matematika memerlukan strategi dengan empat tahapan yang meliputi:

1. Pemahaman masalah

2. Perencanaan penyelesaian

3. Pelaksanaan rencana penyelesaian

4. Pengecekan kembali kebenaran penyelesaian

Indikator sekaligus pendekatan yang menunjukkan kemampuan pemecahan masalah matematis siswa dalam penelitian ini berdasarkan tahapan pemecahan masalah menurut Polya yang dilihat dari kemampuan memahami masalah, merencanakan penyelesaian, melaksanakan penyelesaian dan memeriksa kembali kebenaran penyelesaian.

Tujuan penelitian ini adalah mengembangkan dan menghasilkan LKS berbasis Realistics Mathematics Education (RME) dengan pendekatan problem solving yang valid dan praktis serta dapat memfasilitasi dan meningkatkan kemampuan pemecahan masalah matematis siswa Sekolah Dasar 
(SD). LKS dijadikan sebagai salah satu pengembangan bahan ajar sebagai perantara agar materi pembelajaran yang belum diketahui dan tidak dipahami siswa bisa disampaikan dan dipahami dengan baik.

\section{METODE}

Jenis penelitian ini adalah penelitian pengembangan $(R \& D)$. Metode penelitian dan pengembangan atau dalam bahasa Inggrisnya Research and Development adalah metode penelitian yang digunakan untuk menghasilkan produk tertentu, dan menguji keefektifan produk tersebut (Sugiyono, 2013:407). Pada penelitian ini, produk yang dihasilkan adalah LKS berbasis RME dengan pendekatan Problem Solving pada materi matematika siswa kelas III SDN 012 KP. Panjang Airtiris. Model pengembangan yang dilakukan sesuai dengan Model ADDIE. Pengembangan LKS berbasis RME dengan pendekatan problem solving perlu uji validitas dan uji praktikalitas. Uji validitas dilakukan oleh dosen dan guru sebagai validator. Sedangkan uji praktikalitas dilakukan pada siswa kelas III SDN 012 KP.Panjang Airtiris. Penulis memilih Model ADDIE ini karena langkah-langkah desain sistem pembelajarannya relatif sederhana dan dapat diaplikasikan dalam jenjang pendidikan persekolahan. Hal ini sejalan menurut Benny (2009:125) bahwa salah satu model desain sistem pembelajaran yang memperlihatkan tahapan-tahapan dasar desain sistem pembelajaran yang sederhana dan mudah dipelajari adalah model ADDIE. Model ini sesuai dengan namanya, terdiri dari lima fase atau tahap utama, yaitu (A)nalysis, (D)esign, (D)evelopment, (I)mplementation, dan (E)valuation.

Secara umum, teknik pengumpulan data dan instrumen yang digunakan dalam penelitian ini dapat dilihat pada tabel berikut.

Tabel 1 .

Teknik Pengumpulan Data, Instrumen dan Subjek Penelitian

\begin{tabular}{|l|l|l|l|c|}
\hline No. & \multicolumn{1}{|c|}{$\begin{array}{c}\text { Aspek yang } \\
\text { diteliti }\end{array}$} & $\begin{array}{c}\text { Teknik Pengumpulan } \\
\text { Data }\end{array}$ & \multicolumn{1}{|c|}{ Instrumen } & Subjek \\
\hline 1. & Validitas & Angket & $\begin{array}{l}\text { Lembar validasi LKS } \\
\text { berbasis RME pendekatan } \\
\text { Problem Solving }\end{array}$ & $\begin{array}{c}\text { Dosen dan } \\
\text { Guru }\end{array}$ \\
\hline 2. & Praktikalitas & Angket & $\begin{array}{l}\text { Lembar praktikalitas LKS } \\
\text { berbasis RME pendekatan } \\
\text { Problem Solving }\end{array}$ & Siswa \\
\hline 3. & $\begin{array}{l}\text { Kemampuan } \\
\text { pemecahan } \\
\text { masalah } \\
\text { matematis siswa }\end{array}$ & Tes & Lembar soal posttest & Siswa \\
\hline
\end{tabular}

Teknik analisis data yang digunakan adalah teknik analisis deskriptif. Adapun data yang dianalisis yaitu:

1. Analisis hasil uji kevalidan LKS

Untuk menentukan kevalidan LKS dapat mengikuti langkah-langkah berikut: 
a. Menghitung jumlah skor jawaban yang diperoleh dari angket dan menentukan skor total.

b. Memberikan persentase nilai

$$
\text { Tingkat validitas }=\frac{\text { jumlah skor yang diperoleh }}{\text { jumlah skor total }} \times 100 \%
$$

c. Menginterpretasikan data

$$
\begin{array}{ll}
81 \%-100 \% & : \text { Sangat valid } \\
61 \%-80 \% & : \text { Valid } \\
41 \%-60 \% & : \text { Cukup valid } \\
21 \%-40 \% & : \text { Kurang valid } \\
0-20 \% & : \text { Tidak valid }
\end{array}
$$

(Riduan, 2011:21-22)

2. Analisis hasil uji praktikalitas LKS

Untuk menentukan kepraktisan LKS mengikuti langkah-langkah berikut:

a. Menghitung jumlah skor jawaban yang diperoleh dari angket dan menentukan skor total.

b. Memberikan persentase nilai

$$
\text { Tingkat praktikalitas }=\frac{\text { jumlah skor yang diperoleh }}{\text { jumlah skor total }} \times 100 \%
$$

c. Menginterpretasikan data

$$
\begin{array}{ll}
81 \%-100 \% & : \text { Sangat praktis } \\
61 \%-80 \% & : \text { Praktis } \\
41 \%-60 \% & : \text { Cukup praktis } \\
21 \%-40 \% & : \text { Kurang praktis } \\
0 \%-20 \% & : \text { Tidak praktis }
\end{array}
$$

3. Analisis Tes Kemampuan Pemecahan Masalah

Kemampuan pemecahan masalah siswa dilihat dari skor yang diperoleh siswa setelah diberikan soal tes kemampuan pemecahan masalah yang terdiri dari 5 butir. Untuk menentukan nilai siswa, jawaban tes siswa dianalisis dan ditentukan skornya dengan menggunakan pedoman penskoran kemampuan pemecahan masalah. Skor yang diperoleh siswa dalam posttest dirubah menjadi nilai dengan menggunakan rumus berikut:

$$
\mathrm{S}=\frac{\mathrm{R}}{\mathrm{N}} \times 100
$$

Keterangan:

$\mathrm{S} \quad$ : nilai yang diharapkan (dicari)

$\mathrm{R}$ : jumlah skor dari item atau soal yang dijawab benar

$\mathrm{N}$ : skor maksimum dari tes tersebut

(Purwanto, 2012:112)

Nilai yang diperoleh menunjukkan ketuntasan belajar siswa. Siswa dikategorikan tuntas jika nilai hasil belajar yang diperoleh minimal 70, yaitu sesuai dengan KKM di sekolah. Nilai 
yang diperoleh siswa akan dihitung persentase tingkat kemampuan pemecahan masalah untuk menggambarkan kemampuan pemecahan masalah matematika siswa dengan menggunakan kategori berikut:

$$
\begin{aligned}
& 81 \%-100 \% \quad: \text { Sangat baik } \\
& 61 \%-80 \% \quad \text { : Baik } \\
& 41 \%-60 \%: \text { : Cukup baik } \\
& 21 \%-40 \% \quad \text { : Kurang baik } \\
& \leq 20 \% \quad \text { : Sangat tidak baik } \quad \text { (Widoyoko, 2009:242) }
\end{aligned}
$$

\section{HASIL DAN PEMBAHASAN}

\section{Analisis Validasi}

\section{Validasi Ahli Desain}

Data yang telah dikumpul kemudian dianalisis dan dari hasil analisis menunjukkan bahwa LKS berbasis RME dengan yang telah dikembangkan termasuk dalam kriteriavalid dengan tingkat validitas adalah $78 \%$ dan layak digunakan sebagai bahan pembelajaran. Namun sebagaimana saran yang telah diberikan yaitu tentang penggunaan gambar dan huruf dalam LKS, menurut ahli desain pemilihan huruf pada cover harus jelas, karena ukuran dan jenis huruf yang digunakan sebelumnya masih kurang jelas. Selanjutnya dalam penggunaan gambar pada cover tidak sesuai, yang seharusnya divisualisasikan dengan unsur matematis yang sesuai dengan materi dalam LKS tersebut serta perlu penyantuman sumber gambar. Hasil validasi yang dilakukan oleh ahli desain pada setiap aspek dapat diinterpretasikan sebagai berikut:

1) Dari segi format penulisan, LKS berbasis RME sudah termasuk dalam kriteria cukup valid dengan persentase $60 \%$, dengan rincian sebagai berikut:

a) Pemilihan jenis dan ukuran huruf dengan persentase $60 \%$, ini dikarenakan jenis dan ukuran huruf pada cover yang terlalu kecil sehingga sulit untuk dibaca. Saran dari ahli desain adalah agar pengunaan huruf pada cover diganti dan ini telah direvisi sehingga sudah dapat diujicobakan.

2) Dari segi bahasa, LKS berbasis RME sudah termasuk dalam kriteria valid dengan persentase $70 \%$, dengan rincian sebagai berikut:

a) Bahasa yang digunakan mudah dipahami dengan persentase $60 \%$, yang berarti bahwa tingkat penggunaan bahasa dalam LKS cukup baik, namum perlu diperbaiki supaya bisa dipahami lagi oleh siswa.

b) Bahasa yang digunakan komunikatif dengan persentase $80 \%$, yang berarti bahwa penggunaan bahasa dalam LKS sudah komunikatif.

3) Dari segi tampilan, LKS berbasis RME sudah termasuk dalam kriteria sangat valid dengan persentase $84 \%$, dengan rincian sebagai berikut:

a) Tampilan halaman sampul LKS dengan persentase $80 \%$, yang berarti bahwa desain cover/halaman sampul sudah memiliki daya tarik yang cukup baik. 
b) Desain tampilan dan isi LKS dengan persentase $80 \%$, yang berarti bahwa desain tampilan dan isi LKS sudah memiliki daya tarik yang sangat baik.

c) Pemilihan warna untuk tampilan LKS dengan persentase $80 \%$, yang berarti bahwa untuk tampilan LKS, warna yang digunakan sudah tepat.

d) Ketepatan layout pengetikan pada penyusunan LKS dengan persentase $80 \%$, yang berarti bahwa layout pengetikan sudah tepat.

e) Kemenarikan produk LKS berbasis RME secara keseluruhan dengan persentase $100 \%$, yang berarti bahwa dari segi desain produk LKS ini sudah memiliki daya tarik yang baik.

4) Dari segi penempatan gambar, LKS berbasis RME sudah termasuk dalam kriteria valid dengan persentase $80 \%$, dengan rincian sebagai berikut:

a) Penggunaan gambar sesuai dengan ilustrasi soal dengan persentase $60 \%$, yang berarti bahwa penggunaan gambar sudah cukup sesuai dengan ilustrasi soal dalam LKS, namun perlu disempurnakan lagi terutama permasalahan yang cukup tinggi, perlu adanya penggunaan gambar yang jelas.

b) Penempatan gambar jelas dan sesuai dengan persentase 100\%, yang berarti bahwa gambar-gambar dalam LKS sudah ditempatkan pada tempat yang sesuai.

a. Validasi Ahli Materi

Data yang telah dikumpul kemudian dianalisis dan dari hasil analisis menunjukkan bahwa LKS berbasis RME dengan pendekatan problem solving yang telah dikembangkan termasuk dalam kriteria sangat valid dengan tingkat validitas adalah 83,99\% dan layak digunakan sebagai bahan pembelajaran. Hasil validasi yang dilakukan oleh ahli materi pada setiap aspek dapat diinterpretasikan sebagai berikut:

1) Dari segi isi atau materi, LKS berbasis RME sudah termasuk dalam kriteria sangat valid dengan persentase $83,33 \%$, dengan rincian sebagai berikut:

a) Kesesuaian judul dengan materi pembelajaran dengan persentase $100 \%$, yang berarti bahwa pemilihan judul sudah sesuai dengan materi pembelajaran.

b) Materi pada LKS sesuai dengan Kurikulum yang berlaku dengan persentase $80 \%$, yang berarti bahwa penyajian materi sudah berdasarkan Kurikulum yang berlaku sekarang, yaitu Kurikulum Tingkat Satuan Pendidikan (KTSP).

c) Bahasa yang digunakan mudah dipahami siswa dengan persentase $80 \%$, yang berarti bahwa penggunaan bahasa dalam LKS dapat dipahami siswa dengan mudah.

d) Penggunaan bahasa dalam LKS komunikatif dengan persentase 90\%, yang berarti bahwa bahasa yang digunakan dalam LKS sudah komunikatif.

e) Materi dalam LKS sesuai dengan pengalaman atau tingkat belajar yang dirumuskan dalam silabus dengan persentase $80 \%$, yang berarti bahwa materi yang disajikan sudah sesuai dengan pengalaman atau tingkat belajar yang dirumuskan dalam silabus. 
f) Kesesuaian cakupan materi yang ingin disampaikan dengan tujuan pembelajaran dengan persentase $70 \%$, yang berarti bahwa materi yang disampaikan sudah sesuai dengan tujuan pembelajaran yang diharapkan.

2) Dari aspek tujuan, LKS berbasis RME sudah termasuk dalam kriteria sangat validdengan persentase $86,66 \%$, dengan rincian sebagai berikut:

a) LKS yang dikembangkan dapat memfasilitasi kemampuan pemecahan masalah siswa dengan persentase $90 \%$, yang berarti bahwa kemampuan pemecahan masalah siswa dapat terfasilitasi dengan penggunaan LKS ini, siswa mampu menjawab permasalahan yang diberikan.

b) Tujuan pembelajaran dirumuskan sesuai dengan $\mathrm{SK} / \mathrm{KD} /$ Kurikulum dengan persentase $80 \%$, yang berarti bahwa tujuan pembelajaran sudah dirumuskan dari SK/KD/Kurikulum.

c) Soal latihan dalam LKS dapat mengukur ketercapaian kompetensi dengan persentase $90 \%$, yang berarti bahwa soal latihan yang dibuat sudah dapat mengukur ketercapaian kompetensi siswa.

3) Dari segi berbasis RME dengan pendekatan problem solving, LKS berbasis RME dengan pendekatan problem solving sudah termasuk dalam kriteria sangat valid dengan persentase $83,33 \%$, dengan rincian sebagai berikut:

a) Materi pada LKS disusun dengan menggunakan objek yang ada di lingkungan siswa dengan persentase $80 \%$, yang berarti bahwa materi dalam LKS sudah menggunakan objek yang ada di kehidupan siswa.

b) Mengandung masalah kontekstual yang mudah dibayangkan oleh siswa dengan persentase $80 \%$, yang berarti bahwa materi yang diangkat dalam LKS sudah mengandung masalah kontekstual.

c) Materi yang disusun dapat membuat siswa produktif dan konstruktif dengan persentase $80 \%$, yang berarti bahwa materi dalam LKS sudah dapat membuat siswa menjadi lebih produktif dan konstruktif.

d) Penggunaan LKS yang dikembangkan mampu mengarahkan siswa untuk berinteraksi dalam pembelajaran dengan persentase $80 \%$, yang berarti bahwa LKS sudah dapat menciptakan interaksi dalam pembelajaran.

e) Konsep-konsep yang disajikan pada LKS berkaitan dengan persentase $90 \%$, yang berarti bahwa sudah adanya konsep-konsep yang berkaitan dalam penyusunan LKS.

f) Terdapat model-model, simbol atau skema dalam LKS dengan persentase 90\%, yang berarti bahwa LKS sudah menggunakan model-model, simbol atau skema.

\section{Analisis Praktikalitas}

\section{Praktikalitas Kelompok Kecil}

Analisis praktikalitas kelompok kecil dilakukan untuk mengetahui tingkat kepraktisan LKS yang dikembangkan sebelum diujicobakan kepada kelompok besar. Uji praktikalitas kelompok kecil dilakukan dengan memberikan angket dan LKS berbasis RME dengan pendekatan problem solving kepada 6 orang siswa kelas IV SD Negeri 012 KP.Panjang Airtiris tahun ajaran 2017/2018, hal ini dikarenakan siswa kelas IV sebelumnya yang menjadi siswa kelas III tahun ajaran 2016/2017. 
Menurut siswa, LKS berbasis RME dengan pendekatan problem solving ini sudah memiliki tampilan yang baik dan menarik, materi yang disajikan juga sudah lengkap dan mudah dipahami sehingga bisa menyelesaikan soal dengan baik. Dari hasil analisis uji praktikalitas kelompok kecil dapat dinyatakan bahwa LKS berbasis RME dengan pendekatan problem solving yang telah diujicobakan kepada siswa berkriteria sangat praktis dengan persentase kepraktisan yaitu 93,80\%. Hasil analisis praktikalitas pada setiap aspek dapat diinterpretasikan sebagai berikut:

1) Dilihat dari pemahaman siswa terhadap materi LKS berbasis RME dengan pendekatan problem solving termasuk dalam kriteria praktis dengan persentase 93,33\%, dengan rincian sebagai berikut:

a) Siswa bisa memecahkan masalah/soal dengan persentase $93,33 \%$, ini berarti penggunaan LKS dalam pembelajaran telah dapat membuat siswa memecahkan masalah/soal dengan baik. Siswa mampu menyelesaikan LKS sesuai dengan pendekatan problem solving yang diberikan.

b) LKS berbasis RME dengan pendekatan problem solving memudahkan siswa mempelajari matematika karena berkaitan dengan dunia nyata dengan persentase $93,33 \%$, ini berarti materi yang disajikan dalam LKS sudah berkaitan dengan dunia nyata sehingga sangat baik dalam memudahkan siswa dalam mempelajari matematika.

2) Dilihat dari minat siswa terhadap LKS berbasis RME dengan pendekatan problem solving termasuk dalam kriteria sangat praktis dengan persentase $92,21 \%$, dengan rincian sebagai berikut:

a) Bahasa yang digunakan dapat memudahkan siswa dalam memahami materi dengan persentase 93,33\%, ini berarti bahwa penggunaan bahasa dalam LKS sudah sangat baik.

b) Siswa merasa senang dengan LKS yang dilengkapi dengan gambar yang sesuai dengan ilustrasi soal dengan persentase $86,66 \%$, ini berarti bahwa penggunaan gambar dalam LKS sudah sangat baik sehingga siswa merasa senang dengan LKS.

c) LKS yang dibuat memiliki tampilan yang menarik dengan persentase $96,66 \%$, ini berarti bahwa tampilan LKS sudah sangat baik.

3) Dilihat dari penggunaan LKS berbasis RME dengan pendekatan problem solving termasuk dalam kriteria sangat praktis dengan persentase $96,66 \%$, dengan rincian sebagai berikut:

a) Siswa bisa menggunakan LKS secara mandiri dengan persentase 96,66\%, ini berarti bahwa penggunaan LKS secara mandiri oleh siswa sudah sangat baik.

b) Siswa lebih mudah menggunakan LKS karena terdapat kolom-kolom/kotak isian untuk menjawab soal dengan persentase $96,66 \%$, ini berarti bahwa penggunaaan kolom-kolom/kotak isian pada LKS sudah sangat baik dan membantu siswa dalam menggunakan LKS dalam menjawab persoalan yang diberikan. 


\section{Praktikalitas Kelompok Besar}

Analisis praktikalitas kelompok besar dilakukan untuk mengetahui tingkat kepraktisan LKS yang dikembangkan setelah uji coba kelompok kecil, dengan memberikan angket dan LKS berbasis RME dengan pendekatan problem solving kepada siswa kelas III SD Negeri 012 KP.Panjang Airtiris tahun ajaran 2017/2018. Menurut siswa, LKS berbasis RME dengan pendekatan problem solving ini sudah memiliki tampilan yang baik dan menarik, materi yang disajikan juga sudah lengkap dan mudah dipahami sehingga bisa menyelesaikan soal dengan baik. Dari hasil analisis uji praktikalitas dapat dinyatakan bahwa LKS berbasis RME dengan pendekatan problem solving yang telah diujicobakan kepada siswa berkriteria sangat praktis dengan persentase kepraktisan yaitu 94,07\%. Hasil analisis praktikalitas pada setiap aspek dapat diinterpretasikan sebagai berikut:

1) Dilihat dari pemahaman siswa terhadap materi LKS berbasis RME dengan pendekatan problem solving termasuk dalam kriteria sangat praktis dengan persentase $93,21 \%$, dengan rincian sebagai berikut:

a) Siswa bisa memecahkan masalah/soal dengan persentase $93,57 \%$, ini berarti penggunaan LKS dalam pembelajaran telah dapat membuat siswa memecahkan masalah/soal dengan sangat baik, siswa merasa terbantu dalam memecahkan masalah/soal yang diberikan.

b) LKS berbasis RME dengan pendekatan problem solving memudahkan siswa mempelajari matematika karena berkaitan dengan dunia nyata dengan persentase $92,85 \%$, ini berarti materi yang disajikan dalam LKS sudah berkaitan dengan dunia nyata sehingga sangat baik dalam memudahkan siswa dalam mempelajari matematika.

2) Dilihat dari minat siswa terhadap LKS berbasis RME dengan pendekatan problem solving termasuk dalam kriteria sangat praktis dengan persentase 93,80\%, dengan rincian sebagai berikut:

a) Bahasa yang digunakan dapat memudahkan siswa dalam memahami materi dengan persentase 92,14\%, ini berarti bahwa penggunaan bahasa dalam LKS sudah sangat baik.

b) Siswa merasa senang dengan LKS yang dilengkapi dengan gambar yang sesuai dengan ilustrasi soal dengan persentase 90,71\%, ini berarti bahwa penggunaan gambar dalam LKS sudah sangat baik sehingga siswa merasa senang dengan LKS dan membuat siswa tertarik untuk membaca dan menggunakan LKS.

c) LKS yang dibuat memiliki tampilan yang menarik dengan persentase 98,57\%, ini berarti bahwa tampilan LKS sudah sangat baik, tampilan sudah sesuai dengan kondisi kehidupan sehari-hari siswa.

3) Dilihat dari penggunaan LKS berbasis RME dengan pendekatan problem solving termasuk dalam kriteria sangat praktis dengan persentase $95,71 \%$, dengan rincian sebagai berikut:

a) Siswa bisa menggunakan LKS secara mandiri dengan persentase 97,85\%, ini berarti bahwa penggunaan LKS secara mandiri oleh siswa sudah sangat baik.

c) Siswa lebih mudah menggunakan LKS karena terdapat kolom-kolom/kotak isian untuk menjawab soal dengan persentase 93,57\%, ini berarti bahwa penggunaaan kolom-kolom/kotak isian pada 
LKS sudah sangat baik dan membantu siswa dalam menggunakan LKS dalam menjawab persoalan yang diberikan.

\section{Analisis Kemampuan Pemecahan Masalah Matematika Siswa}

Setelah siswa mengikuti pembelajaran dengan menggunakan LKS berbasis RME dengan pendekatan problem solving ini, siswa diberi soal posttest berupa tes pemecahan masalah matematika. Hasil posttest tersebut menyatakan bahwa terdapat 25 siswa telah tuntas dalam pembelajaran dan 3 siswa tidak tuntas karena nilai yang diperoleh berada di bawah KKM. Namun secara keseluruhan, tingkat kemampuan pemecahan masalah siswa tergolong baik dengan persentase nilai $79,14 \%$. Berikut akan dijelaskan tingkat kemampuan pemecahan masalah matematika siswa tiap indikator kemampuan pemecahan masalah.

a. Indikator pertama yaitu kemampuan dalam memahami masalah dengan tingkat persentase $97,33 \%$. Dengan demikian secara umum siswa telah mampu memahami masalah dengan sangat baik.

b. Indikator kedua yaitu dalam merencanakan penyelesaian sudah mencapai tingkat persentase $88,11 \%$. Dengan demikian secara umum siswa telah mampu membuat rencana penyelesaian masalah dengan sangat baik.

c. Indikator ketiga yaitu kemampuan dalam melaksanakan penyelesaian dengan tingkat persentase 95,22\%. Dengan demikian secara umum siswa telah mampu melaksanakan penyelesaian sesuai dengan perencanaan penyelesaian dengan baik.

d. Indikator keempat yaitu memeriksa kembali dengan tingkat persentase 75,35\%. Ini dikarenakan ada sebagian siswa tidak melakukan pengecekan kembali, namun siswa telah mampu memeriksa kembali jawaban yang telah diperolehnya dengan baik.

Berdasarkan rincian hasil analisis tingkat kemampuan pemecahan masalah matematis siswa pada tiap indikator tersebut, tingkat kemampuan pemecahan masalah matematis siswa secara keseluruhan sudah baik dengan tingkat persentase mencapai 79,14\%. Jadi, dapat dikatakan bahwa LKS berbasis RME dengan pendekatan problem solving ini dapat memfasilitasi kemampuan pemecahan masalah matematis siswa dengan baik.

\section{KESIMPULAN}

Berdasarkan hasil penelitian dan pembahasan yang telah diuraikan, maka dapat diberikan kesimpulan terhadap penelitian ini yaitu sebagai berikut:

1. LKS berbasis RME dengan pendekatan problem solving yang dikembangkan dengan materi matematika kelas III Sekolah Dasar semester ganjil dikembangkan sesuai dengan standar kompetensi dan kompetensi dasar yang mana materi-materi yang ada dapat membimbing siswa untuk belajar dengan pemecahan masalah sehingga siswa memiliki minat untuk belajar.

2. LKS berbasis RME dengan pendekatan problem solving yang dikembangkan dengan materi matematika kelas III Sekolah Dasar semester ganjil sangat layak dijadikan sebagai bahan pembelajaran. 
3. LKS berbasis RME dengan pendekatan problem solving yang dikembangkan dengan materi matematika kelas III Sekolah Dasar semester ganjil memberikan dampak yang positif serta efektif terhadap kemampuan belajar matematika khususnya kemampuan pemecahan masalah matematis siswa.

Selain kesimpulan diatas, dapat diuraikan beberapa saran sebagai berikut:

1. Guru sebaiknya sebelum menerapkan pembelajaran dengan LKS ini sudah mempersiapkan bahanbahan yang akan digunakan dalam LKS dan memastikan siswa siap dan mengerti apa saja yang dikerjakan dalam LKS.

2. Untuk menggunakan LKS ini kepada siswa sebaiknya mempertimbangkan alokasi waktu yang ada karena waktu belajar untuk siswa Sekolah Dasar sangatlah terbatas.

3. Perlu kegiatan maksimal dalam menggunakan LKS ini terlebih lagi siswa Sekolah Dasar kelas III masih identik dengan dunia bermain sambil belajar.

\section{DAFTAR PUSTAKA}

Arsaythamby. 2014. How A Realistic Mathematics Educational Approach Affect Students' Activities In Primary Schools?. Malaysia: Jurnal Procedia - Social and Behavioral Sciences No.159 hal. 309 - 313 Elsevier Ltd.

Bayrakdar. 2011. Problem Solving Approaches Of Mathematics Teacher Candidates In Pisa 2003. Turkey: Jurnal Procedia Social and Behavioral Sciences No.15 hal. 3334-3337 Elsevier Ltd.

Benny, A. Pribadi. 2009. Model Desain Sistem Pembelajaran. Jakarta: Dian Rakyat.

BeritaTerkini. 2012, 17 Desember.PrestasiSainsdanMatematika Indonesia Menurun. Hal.13

Chiang. 2015. Ninth Grade Student' Self-Assessment In Science: A Rasch Analysis Approach. Taiwan: Jurnal Procedia - Social and Behavioral Sciences No.176 hal. 200 - 210 Elsevier Ltd.

Kar et al. 2010. The Relation Between The Problem Posing And Problem Solving Skills Of Prospective Elementary Mathematics Teachers. Turkey: Jurnal Procedia Social and Behavioral Sciences No.2 hal. 1577-1583 Elsevier Ltd.

Polya, G. 2006. How to Solve it. Princeton, N. J: Princeton Univercity Press.

Purwanto, Ngalim. 2012. Prinsip-prinsip dan Teknik Evaluasi Pengajaran. Bandung: Rosda.

Riduan. 2011. Skala Pengukuran Variabel-Variabel Penelitian. Bandung: Alfabeta.

Sari, Nenden Mutiara. 2015. Meningkatkan Kemampuan Pemecahan Masalah Matematis dengan Metode Eksplorasi (Jurnal Mathematics Education, ISSN:2477-409X). Universitas Pendidikan Matematika.

Sugiyono. 2013. Metode Penelitian Kuantitatif, Kualitatif dan $R \&$ D. Bandung: Alfabeta.

Widoyoko, Eko Putro. 2009. Evaluasi Program Pembelajaran, Panduan Praktis Bagi Pendidik dan Calon Pendidik. Yogyakarta: Pustaka Belajar. 